\title{
Trend of Microcredit in Bangladesh: A Study on Government and Non-Government Institutions and Banks.
}

\begin{abstract}
The microcredit movement began as an action-research by Prof. Dr. Muhammad Yunus has quickly become a global phenomenon, attracting more than 100 million borrowers world-wide. This program started mid-eighties and their activities increased noticeably higher after 1990. Although non-banking institutions involved in micro finance activities in earlier now nationalized commercial banks, specialized banks and private commercial banks have also started this program in different forms. The study has found that the number of licensed microcredit institutions and their branches are incising year to year. Number of borrowers was 18.89 million in 2009 which become 23.11 million in 2016. In this period the amount of disbursed loan increased by $155.17 \%$ (BDT 306.72 billion to BDT 782.67 billion) which is a notable evidence for the growth of this sector. The micro financing of the nationalized and private commercial banks is also found in increasing trend. Up to 2002 the public commercial and specialized banks are distributed BDT 11237.19 crore and this cumulative amount is become BDT 32822.17 crore up to June 2016.
\end{abstract}

${ }^{1} \mathrm{Md}$. Nezum Uddin

Assistant Professor

Department of Economics \& Banking

International Islamic University Chittagong (IIUC)

E-mail: ripon.ar@gmail.com

${ }^{2}$ Mohammed Jashim Uddin

Assistant Professor

Department of Economics \& Banking

International Islamic University Chittagong (IIUC)

E-mail: grejasim@yahoo.com

Cell: +8801829672194

Keywords: Microcredit, Growth, Banks, Microfinance institutions.

DOI: $10.7176 / J E S D / 10-3-11$

\section{INTRODUCTION}

The inherent tendency of the people is to come out from the cycle of poverty. A very known and desired process to reduce poverty is borrowing loan. At past, the poorer section of society took loan from local traders to conduct their various economic activities. But the interest rate of these borrowings was highest in amount. So the borrowers involved with the cycle of poverty trap. This phenomenon increased their poverty instead of reducing poverty. Besides, they did not go to the financial institution to take loan due to having complexity of procedures of the institutions.

Prof. Dr. Muhammad Yunus ${ }^{1}$ found some women in Jobra ${ }^{2}$ made bamboo stools having lack of funds to purchase the raw materials themselves. Yunus observed that women needs little amount but they were indebted with local traders. They had to collect loan from the local traders with a high interest for purchasing the raw materials. As the condition of loan they would sell their bamboo products at a little mare price than the raw materials and they were never broken cycle of debt in this way. Dr. Yunus lent them fund without interest for collecting raw materials and that was the first initiative of micro-credit. The concept of modern micro-finance is introduced in the mid1970s by Professor Yunus who realized the failure of the abstract theories of poverty reduction of conventional economics.

\footnotetext{
${ }^{1}$ Prof. Dr. Muhammad Yunus Was the professor of economics at the university of Chittagong and founder of Grameen Bank. The concept of micro finance has been recognized by Prof. Yunus. He receives the Nobel Prize in 2006 along with Grameen Bank.

${ }^{2} \mathrm{~A}$ village adjacent to Chittagong University
} 
Today micro-finance is recognized worldwide and a powerful tool to eradicate poverty, women empowerment, emerging and promising financing sector to the financial organization, NGOs and commercial banks.

Micro-finance opens the door for rural and urban unbanked poor to have loan from the different institutions. This access to loan becomes a tool for income generating and poverty alleviation. It is also playing a great role to accumulate savings from rural sector which increases the investment capacity of the country. Number of registered microfinance institutions (MFIs), number of microcredit borrowers and amount of savings are increasing progressively in Bangladesh. Till June 2016 there were 680 licensed microfinance institutions with 16204 branches provided microfinance services among the 2.76 crore member/ clients (MRA Annual Report, 2016).

Microfinance is an economic development system that provides financial services by different microfinance institutions. Microfinance includes some financial products like savings, insurance, loans, remittance for both the poor and near-poor where traditional market fail to provide the appropriate services. Microcredit is a part of microfinance and an extension for small loan for the poor who are not eligible to reach conventional banking service (Amin \& Sheikh, 2011) .

At present the microcredit activities of Bangladesh are well accepted throughout the world. By giving loan, microcredit institutions in Bangladesh provide financial services to the rural people who are deprived, relegated to take part in general banking activities.

In Bangladesh, microcredit programs are not only being conducted by Microcredit Regulatory Authority (MRA) certified microcredit institutions but also Grameen Bank (GB), various program taken by different ministries of government, different public banks and other institutions and some other non-government commercial banks. Microcredit is playing a crucial role along with various development activities taken by the government to achieve sustainable development goal and cross the middle income threshold to be hunger and poverty-free middle income economy by 2021 .

The aim of the study is to assess the activity of microcredit institutions in Bangladesh. The expansion of the microcredit sector through the various variables such as the institution's dimension, amount of loan, number of branches, number of borrowers etc. will be discussed in this present study. The discussion on microcredit programs of various private commercial banks will be presented in this study that has not been observed in others microcredit related research in Bangladesh.

\section{RATIONALE OF THE STUDY}

Microcredit is playing a dominant role in Bangladesh economic perspective. It is keeping an inevitable role especially to the socio-economic development of the rural poor people who are not able to show any collateral to take loan from the formal financial institutions. So some researchers of various disciplines have taken microcredit as their research subject. Huge research and studied had been come up with the microcredit analysis in the last couple of decades. Most of the studies about microcredit have been operated on operation process, loan endowment process, and comparative analysis of various institutions, success and failure history of loan endowment, structural-efficiency of microcredit institutions. So far it is known to the present study that there was no research about the successive progressiveness of various microcredit institutions and commercial banks in Bangladesh. To fill up this gap the present study has been executed.

\section{METHODOLOGY AND DATA SOURCES}

This study has been done analyzing and scrutinizing various reports of Institute of Microfinance (InM), Microcredit Regulatory Authority (MRA), Credit and Development Forum (CDF), Bangladesh Economic Review, Bangladesh Bank, Bangladesh Rural Advancement Committee (BRAC), Grameen Bank (GB), Association for Social Advancement (ASA) and other microcredit institutions. Multifarious growth variables of three promising, prominent and domineering microcredit institution (GB, ASA, BRAC) have been analyzed and discussed in this paper. The growth pattern of different variables like the number of branches, number of borrowers, amount of savings, total income and total expenditure etc. have been discussed in this paper. Moreover, a brief discussion about microcredit program of commercial banks has been reviewed in this study.

\section{LIMITATIONS OF THE STUDY}

This study has been completed by using various published articles and reports of various institutions. Data of all desired variables that had been used to estimate the growth of microcredit sector were not found in a single institution's data set. Different variables data have been collected from different organization. Besides, some variables data were not homogenous in various annual reports even a single year was found different in various 
data sources and in some cases, successive years' data were not found. For example, data of 2013 for private commercial banks in annual report of Bangladesh Economic Review was missing. In this case, the present study used the average of 2012 and 2014 year's data to get the data of the year 2013. Moreover, there was a target to explore the growth patterns of some variables in this paper. But these variables had been cancelled due to lack of sufficiency and consistency of data.

\section{LITERATURE REVIEW}

Microfinance has achieved huge success in Bangladesh made interest worldwide (S. Ahmed, 2009). He used data from different organizations and surveys in Bangladesh and found that the microcredit program is contributing to the development efforts of Bangladesh.

NGOs are providing various services in the rural area of Bangladesh to improve the income and employment position of poor people (Buckland, 1996) This study examined the distributional performance of credit in irrigation and sericulture sector through ASA, BRAC, and PROSHIKA Muk. The paper concludes that though NGOs work with the poor section of the population; their participants are far from becoming very poorest.

Microcredit programs help to add marginal improvement of the beneficiaries' income (Chavan \& Ramakumar, 2002). This study examined NGO-led microcredit program performance in some developing countries like Bangladesh. The practices of repayment of GB loans have resulted in the creation of debt cycles through making fresh loans from money lending.

Role of microfinance and microenterprise in poverty alleviation has been analyzed by (Midgley, 2008) . The results find that the microcredit and microfinance activities facilitated to the creation of small business and accentuated the existing small business in low-income communities.

(S. Ahmed, 2009) Studied the overview of MFIs, their coverage of borrowers and funded activities have been analyzed along with the efficiency of the mechanism of microfinance delivery and examined the obstacles faced by microfinance movement in Bangladesh. As the expansion of microfinance schemes draw attention from all strata of the world especially in Bangladesh, the coverage of microfinance activities peaked approximately 13 million households. It has been shown in this paper that about 40 percent fund of MFIs are used for generating activities like small-scale business, self-employment etc. and rest of the fund is used in other activities. The poverty of microcredit recipients are gradually attenuating. Finally some challenges like lack of new products and new donor, controversy about the service fees, and borrower sustainability have been maintained in this paper.

(Amin \& Sheikh, 2011) tried to find out the obstacles and prospects of microfinance program in Bangladesh. They compared the microcredit operation of GB, BRAC and ASA using similar program evaluation technique. Their study is conducted on the three upzilas in Comilla district. This study found BRAC has crossed Grameen Bank and ASA significantly in all welfare measures.

(F. Ahmed, Siwar, Idris, \& Begum, 2011) conclude in their empirical study in Bangladesh among borrowers and non-borrowers of Grameen Bank that rural women are facilitated most to reduce their poverty by microcredit program. They found that the 'without credit' women have much higher proportion of poverty in terms of incidence, intensity and severity compared to the 'with credit'.

(Islam, Khatun, Hossain, \& Alom, 2012) examined the microcredit schemes of BRAC, Grameen Bank (GB), PROSHIKA, ASA, TMSS, and SSS where 406 members from 8 different districts were interviewed and results revealed that the highest amount of loan (33.7 percent) was taken by GB members, Grameen Bank workers ranked first in terms of field visit (24.9 percent), received highest percentage of interest rate (42.9 percent). The respondents of GB were highly satisfied compared to SSS and poverty reduction due to micro credit was maximum in GB member that covers 22 percent.

(Khatun, Islam, \& Majumder, 2012) analyzed the poverty reduction impact of six different microcredit institutions and found that about 76.1 percent respondents could change their poverty condition by their own perception although according to poverty change index which is 50.5 percent. However, education index and wealth index have been used to evaluate the change in poverty condition.

(Rahman, Luo, Ahmed, \& Xiaolin, 2012) studied operational mechanism of three dominating microfinance provider ( GB, ASA, BRAC). Their research found the superiority of the three in microfinance regime. Micro- 
credit, saving, social services to the poor are able to demonstrate the sustainable development for the poor villagers and slum areas of Bangladesh. This success may be lesson for the other country as the effort of poverty reduction. (Assefa, Hermes, \& Meesters, 2013) examined the relationship between competition and the performance of microfinance institution by constructing Lerner Index. They used data for 362 MFIs in 73 countries over the period 1995-2009. Their analysis provided the negative association between competition of MFIs and various measures of performance.

(Al Mamun, Hasan, \& Rana, 2013) liked to find out the correlation between poverty and microfinance in Bangladesh. They used descriptive survey method with stratified random sampling and convenience sampling. They found there is a significant difference between (i) microfinance and conventional saving rotating system ${ }^{1}$ in Bangladesh (ii) loan repayment and poverty reduction in Bangladesh.

In their paper (Sharif \& Islam, 2017) efficiency comparison between Grameen Bank (GB) and ASA have been examined in Bangladesh and found the portfolio business of ASA is more diversified than GB. GB's ROE is falling compared to ASA and operating expense ratio and portfolio risk ratio are almost same for both of them. In spite of having more members of GB, it has fewer branches than ASA.

The prospects of microfinance were analyzed in Bangladesh territory by (Ullah \& Haq, 2018). The results exhibit the resilience and regular contribution of Bangladesh microfinance sector to the improvement of macroeconomic growth, and the increasing pattern of various indicators of microfinance institutions by using MRA-MIS database. They also predict the uncertainty of the conventional working market to be able to pick about 2.5 billion young people to provide facilities as they will be older after 20 years by this demographic boom. Thus the microfinance contribution may be fostered and facilitated by creating auto entrepreneurship and the gravity of microfinance can remain crucial in the world market economy.

\section{OVERVIEW ON MICROCREDIT INSTITUTIONS AND SOURCES OF FUNDS}

After 1990 on the basis of number of institutions and clients microfinance institution (MFIs) is an increasing sector in the rural financial market in Bangladesh. About 680 microfinance institutions in Bangladesh are conducting microcredit programs, but ten large institutions and Grameen Bank solely represent 87 percent and 81 percent of total saving and total outstanding.

Microcredit activities are mainly implemented by six types of institutions in Bangladesh (Haque \& Rashid, 2002). These are:

1. Grameen Bank

2. Various Non-Governmental organizations (NGO) like BARC, Proshika, ASA, BURO-Tangil, BEES, CODEC, SUS, TMSS, and Action-Aid etc. Around 1500 NGOs are giving micro-credit across the country.

3. Nationalized commercial banks

4. Specialized banks like Rajshahi Krishi Unnayan Bank, Bangladesh Krishi Bank.

5. Government sponsored micro-finance project like BRDB, Swarnivar Bangladesh etc. which are run through some ministries.

6. Private commercial banks. Now a days some of the private commercial banks have started microcredit program directly or linkage with NGOs.

Once upon a time Bangladesh microfinance market were highly subsidized and donor dependent. Recently donation and subsidy dependency is decreasing and the most important sources of fund are: member's savings, loan from commercial banks, donor organization (internal and foreign agencies), Palli Kama Sahayak Foundation (PKSF), government and various institutions. The member's savings of this section has been increased 26 percent in 2016 compared to previous year 2015 and the amount is tk. 17 thousand 67 crore that covers 34.42 percent of total fund of the current microcredit sector. The second largest source of fund is capital fund which covers 33.67 percent. There is a fluctuation of collecting fund from PKSF. PKSF lent Taka 244.4 billion in 2016 which was Taka 213.8 billion in 2015 crore (Bangladesh Bank, 2016). Although there is a slight improvement of fund of PKSF in 2016 compared to 2015, the dominancy in microcredit sector of PKSF has been slightly decreased from 9.47 percent in 2015 to 8.22 percent in 2016. The share and amount of microcredit from commercial banks are increasing day by day. It was 17.19 percent in 2015 and in 2016 it becomes 19.16 percent.

\footnotetext{
${ }^{1}$ Rotating Saving System is a group of individuals who agree to meet for a particular period in order to save and borrow together.
} 


\section{NOTE ON LEADING MICROFINANCE INSTITUTIONS}

The success of Jobra experiment encouraged Dr. Yunus to expand and test his method for providing credit and banking services to the rural poor. In 1976 Grameen Bank has been originated and extended in 1979 to the Tangil district. It became an independent financial institute in 1983 under the Grameen Bank ordinance. By July 2017 Grameen Bank reaches 2568 branches with 20138 employees (Grameen Bank, 2017). In 2016 the amount of disbursed loan and cumulative disbursed loan was 1,87,533 million BDT and 1,417,716 million BDT respectively. At the end of 2016 the revenue was 32,115 million BDT, which was 31,352 million BDT in 2015.

After establishing the very easy and convenient method by Grameen Bank, many other NGOs get the inspiration to provide same kind of financial services. At present, Grameen Bank, BRAC and ASA are dominating in microcredit sector (Alamgir, 2010). In December 2007, Forbes Magazine (Forbes, 2007) published a list of the world's top 50 microfinance institutions chosen from 641 microcredit providers where ASA was the first microfinance institution over the world. Among them five other Bangladeshi microfinance provider were included like, Jagorani Chakra Foundation (16th), Grameen Bank (17 $\left.7^{\text {th }}\right)$, Bangladesh Rural Advancement Committee $\left(21^{\text {st }}\right)$, Shakti Foundation for disadvantaged women $\left(35^{\text {th }}\right)$, Integrated Development Foundation $\left(38^{\text {th }}\right)$, Buro Bangladesh $\left(48^{\text {th }}\right)$ (Forbes, 2007).

ASA mainly operate microfinance activity along with a number of non-financial programs was established in 1978 . At the end of December 2008 ASA had 7.28 million clients and loan outstanding was tk. 35,735 million. Although at the very beginning ASA gave loan for the purpose of health, education, nutrition and sanitation related development activities, from 1991 the institution focused exclusively on microfinance related loans. As a result, the dependence on donor by this institution has been reduced and transformed itself as a financially self-controlled and specialized institution. Besides, ASA is working relentlessly not only in Bangladesh but also providing microcredit activities in some area of Latin America and Africa (Grameen Bank, 2008). At present eight million clients are attached with ASA who are finding extensively beneficial to progress their situations. Using the mere different method from Grameen Bank, ASA placed number one (1) in Forbes Magazine in December 2007.

Up to December 2015 the number of branch offices and total number of staff were 2933 and 24,419 respectively. In 2015-16 fiscal year BDT 2, 09,057 million loan was disbursed over the 7.4 million clients. During 2016-17 it is reached in 7.84 million clients and disbursed loan 26,959 crore BDT which was $28.95 \%$ higher than the previous year. At the same time the savings of the clients was 66,619 million BDT which was up by $31.44 \%$ higher than the previous year (ASA, 2017)

Bangladesh Rural Advancement Committee (BRAC) started its journey named Bangladesh Rehabilitation Assistance Committee, has implemented various types of activities through microcredit. In 1974, this institution opened its microfinance activities without collateral to the hardcore poor, landless, particularly to the poor women. BRAC added village outreach program and rural credit and training program that have been added with the organization in the year 1979. Non-formal Primary Education program, livestock program, Rural Enterprise Project and Income Generation for Vulnerable Group Development Program were initiated in 1985. During 20002010, BRAC extended its own development activities in outside territory of Bangladesh like Afghanistan, Srilanka, Tanzania, and Uganda etc. First 40 years BRAC provided more than $\$ 1.9$ billion loans for microcredit program where $95 \%$ clients were women. Till 2016 total borrower reached 5.4 million which is $10 \%$ more than 2015 , in this period total loan disbursement reached USD 3.17 billion and outstanding loan and saving deposits is \$1.6 billion and \$0.5 billion. In 2016 total revenue was \$776 million and total staff was 97,742 (BARC, 2017).

\section{PENETRATION OF THE COMMERCIAL BANKS IN MICRO CREDIT SECTOR}

By following the success of Grameen Bank and other microcredit institutions, formal banks ${ }^{1}$ of the country took initiatives and began microfinance activities and from 1994 all commercial banks entered into microcredit realm. Commercial banks began their microfinance programs to achieve commercial viability and alleviate poverty.

Table-2 and Table-3 have shown the status of microcredit of private and public commercial banks. Till 2017 the nationalized commercial and specialized banks cumulatively disbursed and recovered amount are Tk. 43,583.59 crore and Tk. 46,266.98 crore respectively. From 2009 to June 2017 Sonali Bank disbursed Tk. 15,654.30 crore cumulatively which is the maximum among the nationalized commercial banks. In 2009-10 fiscal year Sonali Bank has given Tk. 755.57 crore and in 2016-17 core fiscal year these amount become Tk. 1187.30 crore. Average growth rate of loan distribution over the period is more than 7 percent. Total 7446507 poor people are benefited from the microcredit program of Sonali Bank from 2009 to till now. Up to June 2017 the cumulative loan disbursed

\footnotetext{
${ }^{1}$ All nationalized and private banks (commercial, specialized and foreign banks)
} 
amount of Agrani Bank, Janata Bank, and Rupali Bank Ltd. are Tk. 15365 crore, Tk. 9925.22 crore and Tk. 295.53 crore respectively and total beneficiaries of these banks at the same period are 7305217, 2585131 and 31904 respectively. Two specialized banks Rajshahi Krishi Unnayan Bank and Bangladesh Krishi Bank cumulatively disburse Tk. 495.75 crore and Tk.1847.79 crore respectively. Till 2017 these two banks distribute microcredit to 109269 and 1977087 poor people respectively. Amount of disbursement, recovery and number of beneficiaries of these six banks are increasing gradually.

Private commercial banks have launched micro financial services too. Islami Bank Bangladesh (IBBL) began its microcredit activities from 1995 naming Rural Development Scheme (RDS). RDS related programs are being continued along with commercial banking operation by IBBL. The total member reached 589,280 till March, 2009. In 2004, the RDS network expanded their services among 4230 villages of the country and in 2009 it reached to 10,682 villages. Up to June 2017 IBBL distribute Tk. 18251.91 crore microcredits among 1063588 poor people where 872142 are female.

Al-Arafah Islami Bank Ltd. distributes BDT 12061.68 lac microcredit in 2015-16 fiscal year and its loan outstanding is BDT 6982.54 lac in this period. This bank distributes microcredit among 36469 people since its inception.

\section{OVERALL GROWTH ANALYSIS}

From the graphs of year-based activities of microcredit institutions it is observed that the micro-credit sector of Bangladesh is acquiring huge growth sequentially. All indexes along with loan outstanding and loan disbursement are increasing sequentially. As a result of increasing per head income of the members, the saving and loan paying capacity compared to before has been increased. The average rate of repaying loan in microcredit sector is approximately 98 percent. So the gravity of microcredit is increasing not only in the soil of Bangladesh but also throughout the world that is beyond description. 3.5 crore poor, relegated and deprived people are receiving financial services through the microcredit institutions since inception in Bangladesh. In 2015-16 fiscal year about 1 lack 5 thousand 57 crore taka has been disbursed to 3.17 crore people through all microcredit institutions. Among this only MRA certified institutions distributed TK. 78,000 crore in same fiscal year. The amount of total outstanding loan is 61 thousand 8 hundred 76 crore taka and savings of the members is 37 thousand 2 hundred crore taka where outstanding loan of MRA certified institutions are 45 thousand 4 hundred 1 crore taka and savings is 17 thousand crore taka. Per head saving of the member has been increased dramatically due to expanding income generating programs through microcredit. About 91 percent clients are female in microcredit sector in Bangladesh. The growth of all microfinance institutions certified by MRA from 2009 to 2016 has been shown in Table-4. Number of borrower was 18.89 million in 2009 compared to 23.11 million in 2016. All microfinance institutions disbursed loan BDT 306.72 billion in 2010 that reached 782.67 billion in 2016 and the loan disbursement has been increased $155.17 \%$ within this time. Loan recovery situation of this sector was mentionable during this period. Loan recovery was 280.70 billion in 2010 that peaked 773 billion (175.38\%) in 2016. The advancement of member savings BDT 40.53 billion compared to 170.62 billion in 2016 . The number of employee or staffs in this sector is increasing day by day. The amount of outstanding loan was 143.13 billion in 2009 that reached 454.01 billion in 2016. Thus, the role of microcredit to make a rich and prosperous nation is increasing day by day.

\section{CONCLUDING REMARKS}

Microfinance movement of Bangladesh had been showing paramount across the world since the launching of the concept. By effective and proper regulation, the microfinance remained herald to formalize and devise different lower-class related policies till today. This sector in Bangladesh has evolved as stable and matures not only by the number of beneficiaries but also by the borrowers. At present microfinance sector is overcoming a very momentum moment in Bangladesh. Grameen Bank has conducted to disburse microcredit activities till 2017 through 2568 branches and 20138 employees which disbursed 169,330 million BDT loans in 2016 compared to 45900 million BDT in 2006. ASA and BRAC disbursed 43,000 million BDT and 36,900 million BDT microcredit in 2006 respectively that has been increased by 209,050 million BDT and 218,510 million BDT respectively in 2016. The growth of microfinance institutions has been observed too by analyzing MRA-MIS Database. In 2009 there were 419 institutions but in 2016 that has been reached 680 and disbursed was 261.18 billion BDT in 2009 which has been reached by 782.67 billion BDT in 2016. Microcredit activities of commercial banks in recant year has been observed in Bangladesh. Private commercial bank Islami Bank Bangladesh Limited is ahead than other banks and in 2009-10 fiscal year the bank disbursed 691.11 crore BDT microfinance that reached 3497.75 crore BDT in 2016-17 fiscal year. Despite the lower disbursement rate of loans by Sonali Bank in 2016-17 fiscal year (187.30 crore BDT), remarkable enhancement by Janata and Agrani Bank has been observed in same fiscal year and they 
distributed 751.34 crore BDT and 898 crore BDT respectively where recovery rate was 61 percent and 88 percent respectively.

Micro Credit Regulatory Authority (MRA) and other microfinance regulatory institutions are working relentlessly along with other small scale microcredit institutions to achieve united nation adopted sustainable goals by alleviating poverty, empowering women, eradicating discrimination against women, accelerating social security, creating small scale entrepreneurs, increasing income of the poor class people, improving the living standard of people.

The following key factors led the growth of microfinance (Zaman, 2004):

1. The steadfast vision, study, efficiency of the founders of microfinance organizations are the keys to the success of microfinance industry in Bangladesh. Getting loan by the poor-class people has been established as a quality due to the prominent leadership of the founders. Qualified staffs recruitment and their motivation, decentralization of the branches from the centre, philanthropic activities learned from past wrongness played a significant role to expand microfinance sector.

2. Associate macroeconomic policy, positive control by the government, and favorable environment accelerated the development of this sector. Single digit inflation rate existed during the first decade and economic growth was more than 5 percent that created economic opportunity for micro financing in the economy.

3. Sufficient fund in suited time and constructive role provided by the donors played a crucial role to easily expand the activities of NGOs.

4. High density of population, cooperative indigenous group, social and cultural adjustment easily accelerated and fructified the microcredit model.

5. The researchers of microcredit sector opine that the vulnerability of the poor people has been reduced significantly due to microcredit expansion. The lower-class people can consume in a more sustained and reliant way. The seasonal demands by them is being significantly fulfilled through receiving microcredit even they are adapting themselves with the unexpected hit of natural disaster by taking microcredit loan. This tendency by the lower class people to keep them in a feasible position of poverty made growth of microcredit sector.

6. Health related issues for infant-learning, advanced nutritious related program included in the microcredit program are playing major role to increase and sustain the public acceptance of this sector day by day.

\section{References}

Ahmed, F., Siwar, C., Idris, N. A. H., \& Begum, R. A. (2011). Microcredit's contribution to the socio-economic development amongst rural women: A case study of Panchagarh District in Bangladesh. African Journal of Business Management, 5(22), 9760.

Ahmed, S. (2009). Microfinance institutions in Bangladesh: achievements and challenges. Managerial Finance, 35(12), 999-1010.

Al Mamun, C. A., Hasan, M. N., \& Rana, A. (2013). Micro-credit and poverty alleviation: The Case of Bangladesh. World, 3(1).

Alamgir, D. A. (2010). State of microfinance in Bangladesh. Dhaka: Institute of Microfinance (InM). URL: http://www. inm. org. bd/publication/state_of_micro/Bangladesh. pdf.

Amin, R., \& Sheikh, R. (2011). The impact of micro-finance program on the poor: A comparative study of Grameen Bank, BRAC and ASA in some selected areas in Bangladesh. European Journal of Business and Management, 3(4), 346-364.

ASA Annual Report, (2006-2017)

Assefa, E., Hermes, N., \& Meesters, A. (2013). Competition and the performance of microfinance institutions. Applied Financial Economics, 23(9), 767-782.

Bangladesh Bank, Annual Report, (2006-2017)

Bangladesh Economic Review, Annual Report, (2006-2017)

BRAC Annual Reports, (2006-2017) 
Buckland, J. (1996). The distributional impact of income-generation programmes in Bangladesh. Canadian Journal of Development Studies/Revue canadienne d'études du développement, 17(3), 385-404.

Chavan, P., \& Ramakumar, R. (2002). Micro-credit and rural poverty: An analysis of empirical evidence. Economic and Political weekly, 955-965.

Credit and Development Forum (CDF), Annual Report, (2006-2017)

Grameen Bank, Annual Report, (2006-2017)

Haque, K. M., \& Rashid, L. (2002). Microfinance in Bangladesh. Paper presented at the Paper for the SAARC finance seminar on.

Institute of Microfinance (InM), Annual Report, (2006-2017)

Islam, M. A., Khatun, M., Hossain, D., \& Alom, J. (2012). Micro-credit programmes of different NGOs/MFIs: A comparative study. Journal of the Bangladesh Agricultural University, 10(2), 297-302.

Khatun, M. A., Islam, M. A., \& Majumder, S. (2012). Impact of micro-credit programmes on poverty alleviation in Bangladesh. Bangladesh Journal of Agricultural Economics, 35(1-2).

Microcredit Regulatory Authority, Annual Report, (2006-2017)

Midgley, J. (2008). Microenterprise, global poverty and social development. International Social Work, 51(4), 467-479.

Rahman, M. W., Luo, J., Ahmed, S., \& Xiaolin, W. (2012). The synthesis of Grameen Bank, BRAC and ASA microfinance approaches in Bangladesh. World Applied Sciences Journal, 20(7), 1055-1062.

Sharif, A. M., \& Islam, S. (2017). Efficiency in Social Business Operations: Comparison between Grameen Bank and ASA.

Ullah, A., \& Haq, M. N. (2018). Micro financing management and its prospects: A case study analysis on Bangladesh perspective. South Asian Journal of Marketing \& Management Research, 8(2), 38-46.

Zaman, H. (2004). Microfinance in Bangladesh: growth, achievements, and lessons. SCALING UP POVERTY REDUCTION, 47. 
Appendix Tables

Table-1: Microcredit activities by the commercial banks in 2015-2016

\begin{tabular}{|l|l|l|l|}
\hline Name of the Banks & \multicolumn{1}{|c|}{$\begin{array}{c}\text { Number of } \\
\text { Borrowers }\end{array}$} & \multicolumn{1}{c|}{$\begin{array}{c}\text { Loan Disbursement } \\
\text { (BDT Lac) }\end{array}$} & \multicolumn{1}{c|}{$\begin{array}{c}\text { Loan Outstanding } \\
\text { (BDT Lac) }\end{array}$} \\
\hline Sonali Bank Ltd. & 166445 & 5202 & 29375 \\
\hline Rupali Bank Ltd. & 1765 & 968.8 & 4640.18 \\
\hline Janata Bank Ltd. & 6697 & 4679.01 & 15927.41 \\
\hline Bangladesh Krishi Bank. & 16044 & 4818 & 27574.8 \\
\hline Rajshahi Krishi Unnayan Bank. & 585 & 381.71 & 2037 \\
\hline Islami Bank Bangladesh Ltd. & 253914 & 111873.92 & 89382.08 \\
\hline Dhaka Bank Ltd. & --- & 83486.4 & 64852.92 \\
\hline Jamuna Bank Ltd. & 244 & 1073.7 & 2980.02 \\
\hline Bank Asia Ltd. & ---- & ---- & 72.68 \\
\hline Uttara Bank Ltd. & 3528 & 2838.11 & 2374.41 \\
\hline One Bank Ltd. & 70 & 75.55 & 39.18 \\
\hline Al-Arafah Islami Bank Ltd. & 36469 & 12061.68 & 6982.54 \\
\hline Agrani Bank Ltd. & 44123 & 6248.49 & 66678.93 \\
\hline Modhumoti Bank Ltd. & 100 & 6.5 & ---- \\
\hline Social Islami Bank Ltd. & 100 & 557.41 & 372 \\
\hline
\end{tabular}

Source: MRA-MIS Database-2016 
Table-2: Status of Micro-Credit Disbursement of Scheduled Banks (In crore Taka)

\begin{tabular}{|c|c|c|c|c|c|c|c|c|c|}
\hline & & $2009-10$ & $2010-11$ & 2011-12 & $2012-13$ & 2013-14 & 2014-15 & $2015-16$ & $2016-17$ \\
\hline \multirow{3}{*}{ 赔 } & Disbursement & 755.57 & 676.23 & 723.95 & 688.99 & 1063.15 & 1041 & 1127 & 187.30 \\
\hline & Recovery & 678.28 & 812 & 851.24 & 865.72 & 1166.91 & 1244 & 1178 & 1316.08 \\
\hline & Rate of Recovery (\%) & 89.77 & 120.08 & 117.58 & 129.41 & 109.76 & 45 & 46 & 46 \\
\hline \multirow{3}{*}{ 节 } & Disbursement & 487.92 & 33.61 & 847.41 & 798.16 & 602 & 2120.50 & 1782.02 & 898 \\
\hline & Recovery & 400.37 & 66.6 & 878.54 & 830.35 & 528 & 3051.85 & 3007.86 & 996 \\
\hline & Rate of Recovery & 82.06 & 198.16 & 103.67 & 104.03 & 87.71 & 67 & 67 & 88 \\
\hline \multirow{3}{*}{ 焉 } & Disbursement & 631.63 & 722.36 & 726.52 & 736.48 & 737.3 & 715.57 & 744.80 & 751.34 \\
\hline & Recovery & 4002.24 & 512.23 & 553.27 & 525.54 & 641.35 & 698.91 & 691.23 & 769.70 \\
\hline & Rate of Recovery & 63.37 & 70.91 & 76.15 & 71.36 & 58.00 & 59.00 & 58.00 & 61 \\
\hline \multirow{3}{*}{ בี } & Disbursement & 18.61 & 27.68 & 29.22 & 39.04 & 38.23 & 24.89 & 23.41 & 25.67 \\
\hline & Recovery & 17.4 & 19.23 & 19.95 & 37.03 & 40.78 & 29.07 & 19.09 & 12.19 \\
\hline & Rate of Recovery & 93.5 & 69.47 & 68.28 & 94.85 & 106.67 & 101 & 82 & 48 \\
\hline \multirow{3}{*}{ 吾 } & Disbursement & 22.69 & 21.78 & 15.67 & 16.63 & 12.17 & 11.44 & 19.99 & 105.5 \\
\hline & Recovery & 18.89 & 23.79 & 17.63 & 16.68 & 17.38 & 15.71 & 20.33 & 59.69 \\
\hline & Rate of Recovery & 83.25 & 109.23 & 112.51 & 100.3 & 142.81 & 137.32 & 169.09 & 57 \\
\hline \multirow{3}{*}{ 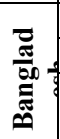 } & Disbursement & 98.49 & 53.42 & 55.22 & 73.70 & 100.49 & 96.56 & 57.61 & 58.28 \\
\hline & Recovery & 76.02 & 51.25 & 53.69 & 51.38 & 109.37 & 106.77 & 52.04 & 36.81 \\
\hline & Rate of Recovery & 77.19 & 96 & 97.23 & 69.72 & 109 & 111 & 53.17 & 63.16 \\
\hline \multirow{3}{*}{ ل } & Disbursement & 1291.17 & 1358.95 & 4807.76 & 4350.41 & 3893.05 & 3529.68 & 3209 & 3829.94 \\
\hline & Recovery & & & & & & & & \\
\hline & Rate of Recovery & 95.48 & -- & 95.48 & 95.4 & 95.32 & 92.60 & 91.32 & 95.25 \\
\hline \multirow{3}{*}{ 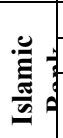 } & Disbursement & 691.11 & 855.93 & 1238.41 & 2544.97 & 3851.53 & 2652.62 & 3345.66 & 3497.75 \\
\hline & Recovery & & & & & & & & \\
\hline & Rate of Recovery & 99 & 99.40 & -- & --- & -- & 93.36 & 99.34 & 99.34 \\
\hline \multirow{3}{*}{ 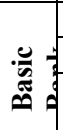 } & Disbursement & 73.49 & 40.89 & 40.51 & 403.75 & 767 & 56.38 & 111.48 & 178.04 \\
\hline & Recovery & & & & & & & & \\
\hline & Rate of Recovery & 98.23 & 98.11 & 95.85 & 195.99 & 98.14 & 98 & 98.86 & 98.24 \\
\hline \multirow{3}{*}{ : } & Disbursement & 324.31 & 1234.23 & 1345.93 & 1767.53 & 2189.14 & 2595 & 8.40 & 6407.92 \\
\hline & Recovery & & & & & & & & \\
\hline & Rate of Recovery & 73.28 & 72.08 & 69.67 & 70.42 & 71.17 & 72.17 & 73.00 & 68.64 \\
\hline
\end{tabular}

Source: Annual Reports of Bangladesh Economic Review 
Table-3: Microcredit operations of the Grameen Bank and large MFIs (In Million Tk.)

\begin{tabular}{|c|c|c|c|c|c|c|c|c|c|c|c|c|}
\hline & & 2006 & 2007 & 2008 & 2009 & 2010 & 2011 & 2012 & 2013 & 2014 & 2015 & 2016 \\
\hline \multirow{5}{*}{ 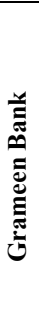 } & $\begin{array}{l}\text { Disbursemen } \\
\mathrm{t}\end{array}$ & $\begin{array}{c}45,90 \\
0\end{array}$ & $\begin{array}{c}50,20 \\
0\end{array}$ & 54,600 & $\begin{array}{c}71,85 \\
0\end{array}$ & $\begin{array}{c}87,54 \\
0\end{array}$ & $\begin{array}{c}102,96 \\
0\end{array}$ & $\begin{array}{c}115,77 \\
0\end{array}$ & $\begin{array}{c}122,01 \\
0\end{array}$ & 117,23 & $\begin{array}{c}139,18 \\
0\end{array}$ & $\begin{array}{c}169,33 \\
0\end{array}$ \\
\hline & $\begin{array}{l}\text { Outstanding } \\
\text { Loan }\end{array}$ & $\begin{array}{c}31,70 \\
0\end{array}$ & $\begin{array}{c}33,80 \\
0\end{array}$ & 34,500 & $\begin{array}{c}50,71 \\
0\end{array}$ & $\begin{array}{c}61,50 \\
0\end{array}$ & 71,690 & 79,840 & 83,940 & 87,730 & 91,290 & $\begin{array}{c}109,39 \\
0\end{array}$ \\
\hline & Recovery & $\begin{array}{c}37,70 \\
0\end{array}$ & $\begin{array}{c}48,00 \\
0\end{array}$ & 48,900 & $\begin{array}{c}61,05 \\
0\end{array}$ & $\begin{array}{c}76,75 \\
0\end{array}$ & 92,770 & $\begin{array}{c}107,36 \\
0\end{array}$ & $\begin{array}{c}117,61 \\
0\end{array}$ & $\begin{array}{c}113,68 \\
0\end{array}$ & $\begin{array}{c}135,63 \\
0\end{array}$ & $\begin{array}{c}181,00 \\
0\end{array}$ \\
\hline & $\begin{array}{l}\text { No. of } \\
\text { Branches }\end{array}$ & 2319 & 2481 & 2,539 & 2,562 & 2,565 & 2,565 & 2,567 & 2,537 & 2,568 & 2,568 & 2,568 \\
\hline & $\begin{array}{l}\text { No. of } \\
\text { Employee }\end{array}$ & 20885 & 25283 & 24,240 & $\begin{array}{l}23,28 \\
3\end{array}$ & $\begin{array}{c}22,25 \\
5\end{array}$ & 22,128 & 22,261 & 21,851 & 21,807 & 21,651 & 21,043 \\
\hline \multirow{5}{*}{$\underset{\pi}{\pi}$} & $\begin{array}{l}\text { Disbursemen } \\
\mathrm{t}\end{array}$ & $\begin{array}{c}43,00 \\
0 \\
\end{array}$ & $\begin{array}{c}52,30 \\
0 \\
\end{array}$ & $\begin{array}{c}53,700 \\
0\end{array}$ & $\begin{array}{c}54,60 \\
0\end{array}$ & $\begin{array}{c}72,92 \\
0\end{array}$ & 77,460 & 94,600 & 96,180 & $\begin{array}{c}102,60 \\
0\end{array}$ & $\begin{array}{c}146,39 \\
0\end{array}$ & $\begin{array}{c}209,05 \\
0\end{array}$ \\
\hline & $\begin{array}{l}\text { Outstanding } \\
\text { Loan }\end{array}$ & $\begin{array}{c}23,20 \\
0\end{array}$ & $\begin{array}{c}24,70 \\
4\end{array}$ & 32,022 & $\begin{array}{c}31,32 \\
3\end{array}$ & $\begin{array}{c}37,52 \\
5\end{array}$ & 44,630 & 55,00 & 55,734 & 59,290 & 87,723 & $\begin{array}{c}154,71 \\
1\end{array}$ \\
\hline & Recovery & $\begin{array}{c}37,40 \\
0\end{array}$ & $\begin{array}{c}47,10 \\
0\end{array}$ & 45,600 & $\begin{array}{c}68,80 \\
0\end{array}$ & $\begin{array}{c}61,39 \\
0\end{array}$ & 68,790 & 84,260 & 95,440 & 99,040 & $\begin{array}{c}117,95 \\
0\end{array}$ & $\begin{array}{c}176,49 \\
0\end{array}$ \\
\hline & $\begin{array}{l}\text { No. of } \\
\text { Branches }\end{array}$ & 2,931 & 3,333 & 3,303 & 3,236 & 3,194 & 3,154 & 3,127 & 2,942 & 2,931 & 2,932 & 2,959 \\
\hline & $\begin{array}{l}\text { No. of } \\
\text { Employee }\end{array}$ & $\begin{array}{l}18,40 \\
0\end{array}$ & $\begin{array}{l}25,12 \\
5\end{array}$ & 25,719 & $\begin{array}{l}24,02 \\
1\end{array}$ & $\begin{array}{c}22,45 \\
8\end{array}$ & 21,422 & 21,263 & 20,419 & 20,294 & 20,294 & 22,927 \\
\hline \multirow{3}{*}{$\frac{U}{\underline{x}}$} & $\begin{array}{l}\text { Disbursemen } \\
\mathrm{t}\end{array}$ & $\begin{array}{c}36,90 \\
0\end{array}$ & $\begin{array}{c}52,70 \\
0\end{array}$ & 75,100 & $\begin{array}{c}80,93 \\
0\end{array}$ & $\begin{array}{c}75,10 \\
0\end{array}$ & 74,940 & 97,720 & $\begin{array}{c}112,65 \\
0\end{array}$ & $\begin{array}{c}133,87 \\
0\end{array}$ & $\begin{array}{c}172,57 \\
0\end{array}$ & $\begin{array}{c}218,51 \\
0\end{array}$ \\
\hline & $\begin{array}{l}\text { Outstanding } \\
\text { Loan }\end{array}$ & $\begin{array}{c}20,90 \\
0 \\
\end{array}$ & $\begin{array}{c}32.00 \\
0 \\
\end{array}$ & 43,000 & $\begin{array}{c}45,40 \\
0 \\
\end{array}$ & $\begin{array}{c}44,59 \\
0 \\
\end{array}$ & 45,580 & 57,140 & 66,450 & 81,170 & $\begin{array}{c}193,46 \\
0 \\
\end{array}$ & $\begin{array}{c}127,83 \\
0 \\
\end{array}$ \\
\hline & Recovery & $\begin{array}{c}37,50 \\
0\end{array}$ & $\begin{array}{c}62,60 \\
0\end{array}$ & 63,700 & $\begin{array}{c}78,77 \\
0\end{array}$ & $\begin{array}{c}75,91 \\
0\end{array}$ & 72,130 & 83,990 & $\begin{array}{c}103,34 \\
0\end{array}$ & $\begin{array}{c}138,39 \\
0\end{array}$ & $\begin{array}{c}150,82 \\
0\end{array}$ & $\begin{array}{c}193,60 \\
0\end{array}$ \\
\hline
\end{tabular}

Source: Annual Reports of Bangladesh Bank and Authors own Calculation

Table -4: Overall Growth of NGO-MFIs in Bangladesh

\begin{tabular}{|l|l|l|l|l|l|l|l|l|}
\hline Particulars & 2009 & 2010 & 2011 & 2012 & 2013 & 2014 & 2015 & 2016 \\
\hline $\begin{array}{l}\text { Number of NGO- } \\
\text { MFIs }\end{array}$ & 419 & 516 & 576 & 590 & 649 & 742 & 753 & 680 \\
\hline Number of Employee & 107,175 & 109,597 & 111,828 & 108,654 & 100,735 & 109,628 & 110,781 & 122,335 \\
\hline Number of Branches & 16,851 & 17,252 & 18,066 & 17,977 & 14,674 & 14,730 & 15,609 & 16,204 \\
\hline Member's Savings & 40.53 & 47.44 & 63.30 & 74.99 & 94.00 & 107.00 & 135.44 & 170.67 \\
\hline Cumulative Surplus & 36.26 & 42.34 & 50.30 & 65.44 & 83.26 & 100.94 & 137.71 & 166.97 \\
\hline $\begin{array}{l}\text { Total borrowers } \\
\text { (Million) }\end{array}$ & 18.89 & 19.21 & 20.65 & 19.31 & 19.27 & 19.42 & 20.35 & 23.11 \\
\hline $\begin{array}{l}\text { Loan Outstanding } \\
\text { (Billion Tk.) }\end{array}$ & 143.13 & 145.02 & 173.79 & 211.32 & 257.01 & 282.20 & 352.41 & 454.01 \\
\hline $\begin{array}{l}\text { Loan Disbursement } \\
\text { (Billion Tk.) }\end{array}$ & 261.18 & 306.72 & 303.18 & 456.02 & 432.28 & 462.00 & 634 & 782.67 \\
\hline $\begin{array}{l}\text { Loan Recovery (Billion } \\
\text { Tk.) }\end{array}$ & ------- & 280.78 & 271.83 & 314.11 & 375.07 & 447.89 & 522.47 & 773 \\
\hline Recovery Rate (\%) & 97.93 & 97.35 & 95.52 & 97.74 & 97.69 & 95.64 & 96.02 & \\
\hline
\end{tabular}

Source: MRA-MIS Database

* Licensed by MRA 